\title{
專門委員会・分科会研究レビュー
}

\section{知的ナノ計測専門委員会 \\ ものづくり基盤の進化からイノベーションの 創出を担う知的ナノ計測* \\ Intelligent Nano-measurement as a Driving Force of Metrology and Innovation}

\section{高谷裕浩**}

Yasuhiro TAKAYA

Key words

intelligent nano-measurement, metrology, traceability, optical comb, areal topography, optical measurement

\section{1.はじめに}

メゾスコピックからサブナノメートル領域の幾何学量を 扱う最先端のものづくりにおいて，新たな技術や機能を創 出するためには，「プロセスの見える化」が不可欠であり， ものづくり基盤としての計測技術は, グローバルな規模で 急速に変化するものづくりに対応するための戦略技術とし て，ますます重要となってきている。本委員会（委員長： 高谷裕浩 (大阪大学) * 2014 年高増潔 (東京大学) 委員 長から交代) は, 「知的ナノ計測研究分科会」(2004 年発 足：委員長 三好隆志 (大阪大学) ) における活動を発展 的に継承することにより，2006 年に設立された。設立以 来一貫して, 計測の基盤である標準や規格のたゆまない進 化を追求する基礎研究から，新たな加工原理や製造技術へ の適用が可能な新計測技術の開拓に至る広範囲なものづく り計測の探求を目的とした活発な活動を展開している.

\section{2. 活動理念：3つの基盤}

本委員会の活動理念を図 1 に示す。計測は, 科学, 技 術および社会的秩序におけるそれぞれの基盤として，その 役割を果たしている。すなわち，学問基盤，技術基盤およ び社会基盤の構築，維持，発展を担う委員会活動は，

1）基礎現象の深い理解に基づいた新たな計測原理の探 求と，それによって獲得された知識の体系化によっ て普遍性の高いメトロロジーや計測科学を構築する,

2）新たな加工原理や製造技術への適用が可能な加工計 測，知的計測および計測システムなど，技術革新の 原動力となる計測技術を開拓する,

3）ものづくりにおける社会的（経済的）秩序を維持す るための, 標準と規格, 校正, トレーサビリティを 整備する,

の 3 つの目的に基づいている.このような委員会活動を, 産官学連携のコアの役目を果たしながら強力に推進し, 革

*原稿受付 平成 27 年 8 月 5 日

*正会 員 大阪大学大学院工学研究科 (大阪府吹田市山田丘 2-1)
新的ものづくりの創出と計測科学の学術体系そのものの変 革を世界的な規模で広げていくことを狙っている。

\section{3. 知的ナノ計測の最新動向}

\section{1 計測基盤の進化}

この 5 年くらいのあいだに，ものづくり計測全体の変革 に関わる，新たな動きが起きており，本委員会の研究開発 の方向性にも影響を与えている.

\subsection{1 新たな長さの国家標準}

ナノスケールものづくりにおける絶対精度を保証するた めには，絶対基準に対する繰り返し測定の平均值がもつ分 布の期待值（母平均）の偏りが高精度に校正された, 高い 正確度をもつ計測技術が必要不可欠である。すなわち加工 の絶対精度は，トレーサビリティに基づいて保証される。 トレーサビリテイ体系の最も頂点にあるのが, 国際単位 SI (Système International d'Unités) における基本単位で ある，長さ（メートル）標準を具現化した国家標準（特定 標準器）であり，その精度は計測機を通して加工精度にも 波及する。1993 年 11 月に特定標準器に指定されて以来 15

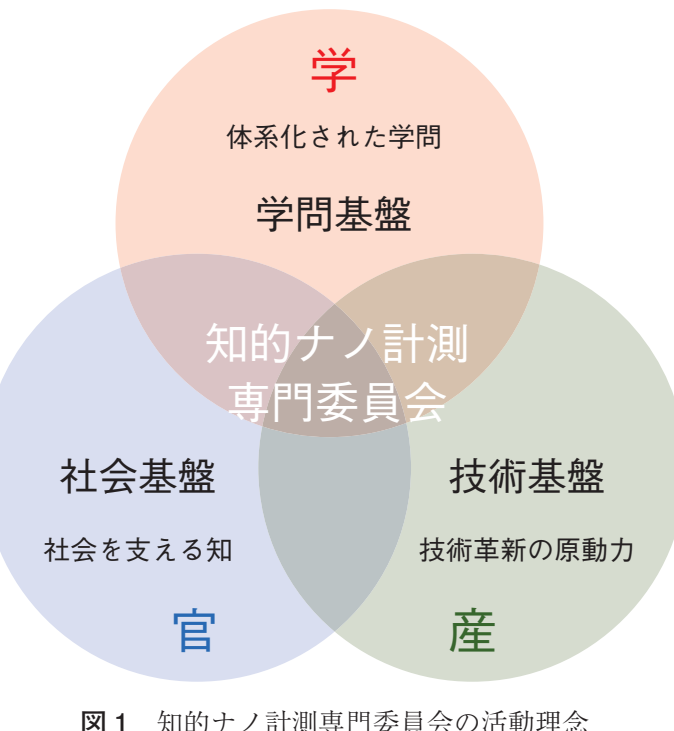

図 1 知的ナノ計測専門委員会の活動理念 


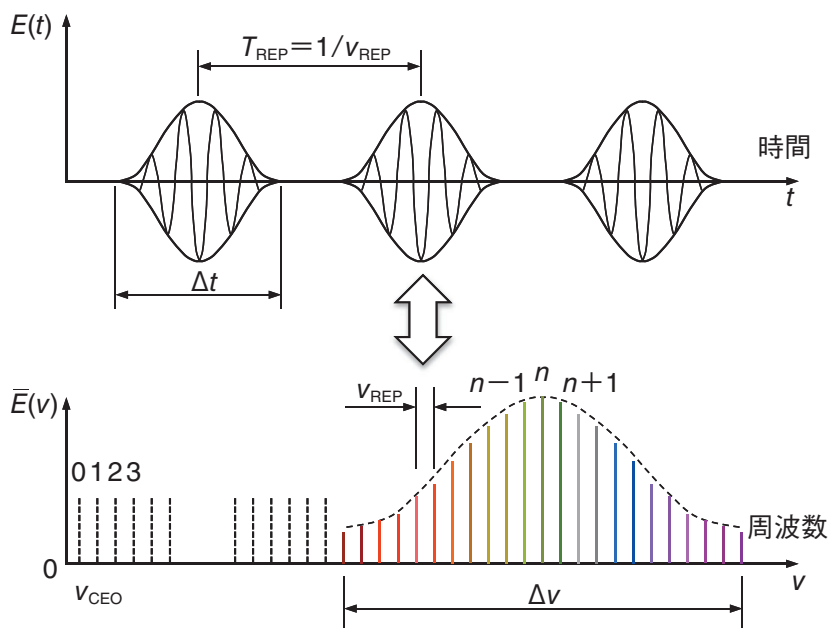

図 2 新たな長さの国家標準 : 光周波数コム

年間, 波長の值 $632991212.579 \mathrm{fm}$ に対し, 12 桁の精度が 保証されている,「長さ用 633 ナノメートルよう素分子吸 収線波長安定化ヘリウムネオンレーザ装置」が国家標準と して用いられてきた。 2009 年 7 月，新たな長さの特定標 準器として，エルビウム添加光ファイバーを増幅媒体とす るモード同期ファイバレーザーとフォトニック結晶ファイ バーから構成される,「協定世界時に同期した光周波数コ 厶装置」が指定された，光周波数コムは，図 2 に示すよ うに, その出力電場 $E(t)$ の時間変化はモード同期パルス レーザーであり，周波数軸のスペクトル $\bar{E}(v)$ は発振モー ドが等しい周波数間隔（モード間隔周波数）で並んでい る。そのため多くの波長に対して光ビートを利用した高精 度な光周波数計測が可能となり，光応用測定機の校正の利 便性が飛躍的に向上し，光周波数の測定精度が 300 倍向上 した（不確かさ $1 / 300 ）$.

\section{1 .2 光学式 3 次元形状計測の規格}

複雑な 3 次元自由曲面形状加工の急速な広がりに対応す るため, 光学式 3 次元形状計測の高精度化と実用化が進ん でいる。そこで，測定機の校正方法やトレーサビリティの 必要性に対する要求に応えるため, 2009 年 9 月にJIS B 7441「非接触座標測定機の受入検査及び定期検査 ${ }^{1)}$ が 制定・公示された。対象物の形状を多点群の三次元座標值 として取得できる非接触座標測定機として,「イメージセ ンサ（CCD カメラなど）の他に，測定のために物体表面 にパターン・テクスチャを投影するプロジェクタ，レーザ 光を投影するシステムなどをもつ光学式センサ，その他の 手法による非接触プロービングシステムを保有する」測定 機が規格の対象とされている，光学式センサの具体例とし て，レーザスリットスキャン，縞投影，スポット光投影， モアレ方式などが挙げられている, 精度評価の方法は, 従 来の CMM（Coordinate Measuring Machine）の校正など でも規定されている、トレーサビリティを確保するための アーティファクトを用いた方法に準拠している。特徵的な のは, 表面の光学特性を規定する項目が挙げられている点

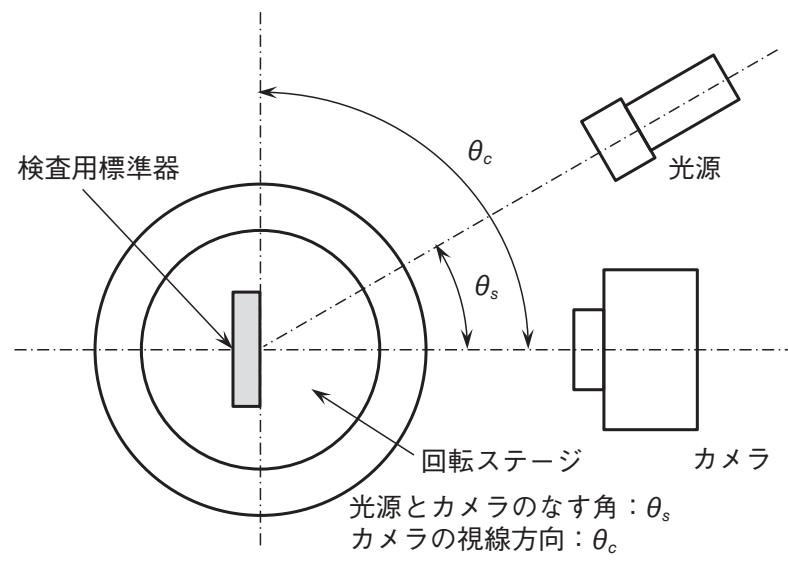

図 3 検査用標準器を用いた表面の光学特性評価法

である. 図 3 に示すように, 光を検査用標準器に投影し， 角度 $\theta_{\mathrm{c}}$ と $\theta_{\mathrm{s}}$ を変化させながら反射光を観測することによ って，測定表面の特性を評価する方法が示されている.

3.1.3 3 次元表面粗さの規格

最近では, サブマイクロメートルからナノメートル単位 で加工制御を行い, 複雑で高度な機能を有する表面微細形 状加工の需要も増している。 しかし, 従来の 2 次元輪郭曲 線に基づいた表面粗さパラメータ2)では, 複雑な 3 次元表 面微細形状や加工精度の評価に十分対応できなくなってき ている. 2012 年には ISO 25178-2 の新たな 3 次元表面粗 さ規格が定められた ${ }^{3)}$. 新たな規格では，コヒーレンス走 査型干渉法や共焦点顕微鏡など, 主に 3 次元プロファイル 計測に適した光学式測定法を分類して提示している。ささら に，3 次元パラメータの規格を生産現場に普及させようと する動きも急速に進んでおり, 最新動向として, 生産現場 に扔ける加工表面の検証や測定機の校正に利便性の高い校 正用標準試料や，生産現場の環境でも利用可能な測定機が 開発されている. 3 次元表面性状パラメー夕の多くは輪郭 曲線 $Z(x)$ から 3 次元プロファイル $Z(x, y)$ への拡張となっ ているが, 自己相関距離やモチーフ解析のような 3 次元卜 ポグラフィ特徵解析など， 3 次元表面性状パラメー夕独自 の評価方法も提示されている.

\section{2 学術としての深化と展開}

本委員会の活動理念を示した図 1 に対応する研究につい て，それぞれ一例を挙げて紹介する。

3.2 .1 学問基盤

基礎現象の深い探求に基づいた新たな計測原理の確立に 挑戦する研究の一例として, 新たな長さの国家標準に基づ いた次世代の距離計測技術に関わる研究が展開されてい る. 光コムのビートを利用する計測手法を提案し, 遠方か ら, 粗面に対して非接触かつ高速で, 高分解能 $(10 \mu \mathrm{m})$ で測距を行う計測手法の有効性を示している4)。 また，蛍 光偏光の物理現象に基づいた新たなナノ粒子粒径計測原理 である周波数領域蛍光法が提案されている。蛍光プローブ 標識金ナノ粒子の回転拡散係数測定によって，提案手法に 


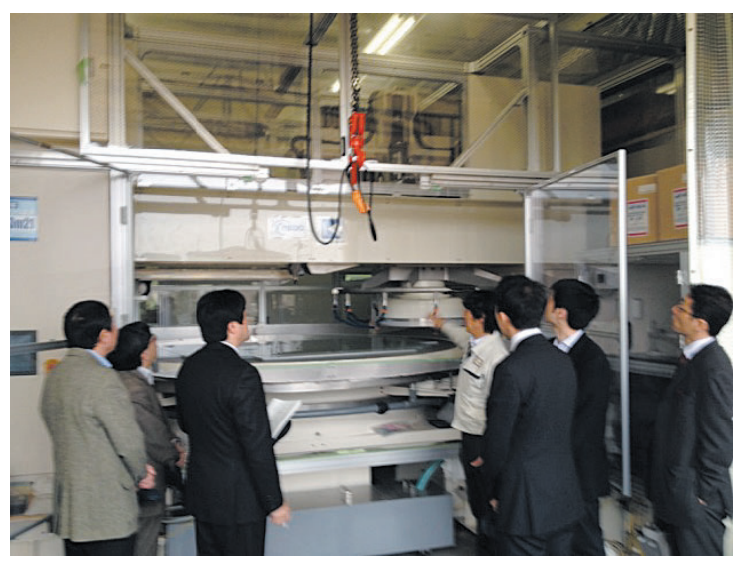

図 4 見学会の様子 ((株)クリスタル光学)

よる粒径計測の妥当性を示している5 ${ }^{5)}$.

3.2 .2 技術基盤

精密加工装置や半導体露光装置向け超精密リニアステー ジにおいては，高精度リニアエンコーダを用いたフィード バック制御による $\mathrm{nm}$ ・サブ $\mathrm{nm}$ オーダの位置決め精度が 要求される。新たな知的精密計測技術の開拓に関する研究 の一例として，測定レーザ光の反射体に回折格子を用いる ことで，シングルレーザ光で測定対象の 3 軸微小回転運動 を一括検出できる光学式 3 軸角度センサの提案と, 実用的 なセンサを用いた実験実証が行われている ${ }^{6)}$.

3.2 .3 社会基盤

薄膜作製や材料表面処理の品質管理のため, 原子間力顕 微鏡（AFM）を用いてナノメートルオーダの表面粗さ測 定が広く行われるようになってきており，より高品質な薄 膜や材料表面を評価するために，より高精度で信頼性の高 い表面粗さ測定が求められている。そこで，標準と規格， 校正，トレーサビリティなどに密接に関連した基礎研究の 一例として，測長原子間力顕微鏡を用いた表面粗さ測定に 関する研究が挙げられる。測長 AFM を用いて各種材料の 表面粗さ測定およびその不確かさ評価が行われている。そ の結果，測長 AFM はナノメートルオーダの表面粗さ測定 にも適用可能であり，表面粗さの規格である JIS B 1683： 2007 も有効であることが示されている77).

\section{4. 活動概要と実績}

前回のレビュー（精密工学会誌, Vol. 76, No. 10, 2010） 以降の活動についてその概要をまとめる。

\section{1 研究会と見学会}

春季および秋季大会の定例委員会および年一回の総会と 研究会（見学会を含む）を開催した。総会では，毎回 2 件 以上の計測および関連分野の最先端動向に関する特別講演 会を実施している。また，研究会では，大阪大学吹田キャ ンパス (2011 年 6 月), (株) 小坂研究所 (2013 年 12 月), (株)クリスタル光学 (2015 年 1 月) を訪問し, 講演会と 見学会を実施して研究交流を図っている（図4）.
表 1 オーガナイズドセッション：知的精密計測の講演件数

\begin{tabular}{|c|c|c|}
\hline 年度 & 春季大会学術講演会 & 秋季大会学術講演会 \\
\hline $\begin{array}{l}2011 \\
\text { 年 }\end{array}$ & $\begin{array}{c}3 \text { 月 } 14 \text { 16日：東洋大学 } \\
\text { 大震災により中止 }\end{array}$ & $\begin{array}{c}9 \text { 月 20 22 日 : 金沢大学 } \\
34 \text { 件 }\end{array}$ \\
\hline $\begin{array}{l}2012 \\
\text { 年 }\end{array}$ & $\begin{array}{c}3 \text { 月 14 16 日：首都大学東京 } \\
35 \text { 件 }\end{array}$ & $\begin{array}{c}9 \text { 月 14 16 日: 九州工業大 } \\
21 \text { 件 }\end{array}$ \\
\hline $\begin{array}{l}2013 \\
\text { 年 }\end{array}$ & $\begin{array}{c}3 \text { 月 13 15 日：東京工業大学 } \\
29 \text { 件 }\end{array}$ & $\begin{array}{c}9 \text { 月 12 14 日：関西大学 } \\
23 \text { 件 }\end{array}$ \\
\hline $\begin{array}{l}2014 \\
\text { 年 }\end{array}$ & $\begin{array}{c}3 \text { 月 18 20日 : 東京 } \\
43 \text { 件 }\end{array}$ & $\begin{array}{c}9 \text { 月 } 16 \sim 18 \text { 日: 鳥耳 } \\
20 \text { 件 }\end{array}$ \\
\hline $\begin{array}{l}2015 \\
\text { 年 }\end{array}$ & $\begin{array}{c}3 \text { 月 } 17 \sim 19 \text { 日：東泩 } \\
35 \text { 件 }\end{array}$ & $\begin{array}{c}9 \text { 月 4 6 日：東北大学 } \\
33 \text { 件 (予定) }\end{array}$ \\
\hline
\end{tabular}

\section{2 オーガナイズドセッション：知的精密計測}

本委員会が主催したオーガナイズドセッション「知的精 密計測」を表 1 にまとめた。毎回 20 件以上の講演発表が あり, 最新計測技術に関する発表と活発な議論が行われて いる.

\section{3 国際会議とシンポジウムの主催}

本委員会では, 表 2 に示すような国際会議とシンポジ ウムを積極的に主催し, 国内外における研究者および企業 技術者などによる学術交流を行っている。まず，国際交流 として，2010 年に計測と品質管理に関する国際会議であ る, ISMQC2010 (10th International Symposium on Measurement and Quality Control, 大阪大学, 実行委員 長：高谷裕浩 (大阪大学)) を主催し，197 名 (外国参加 者 108 名), 発表件数 147 件の盛会となった。さらに, 2014 年に LMPMI2014 (11th Laser Metrology for Precision Measurement and Inspection in Industry, つ< ば国際会議場, 実行委員長：高辻利之 (産総研)）を実施 し, 119 名 (外国参加者 48 名), 発表件数 81 件の実績を 挙げた。

次に, 2012 年の秋季大会学術講演会・国際シンポジウ ムでは, 将来を担う若手研究者と海外の招待講演者より, ナノスケールものづくり基盤としての新たな計測技術の最 新研究開発動向が紹介された。2015 年春季大会では, 国 連（A/RES/68/221）で採択された世界イニシアチブであ る, 国際光年（International Year of Light, IYL2015）を記 念して,「ユネスコ国際光年記念 精密工学会・国際シン ポジウム」を開催した。さらに，2015 年秋季大会でも， 「ユネスコ国際光年記念シンポジウム 知的ナノ光計測の 新展開」を主催して，ものづくりの基盤を支える光計測の 最新動向を紹介する。

\section{4 知的精密計測への理解を深める啓蒙活動}

基礎講習会や学会誌特集記事などは，社会に広く開かれ た学問としての重要な使命である。その活動の一つとし て, 第 367 回講習会「研究室見学付き基礎講座“はかる” を知る, 精密測定の理論と最新動向一基礎原理から最新の 微細久阥精密計測, X 線 CT, 計測機器まで一」(2014 年 6 月）を，精密工学会と精密測定技術振興財団の共催によ って開催した。計測のトレーサビリティや歴史等, 精密測 
表 2 国際会議とシンポジウムの主催

\begin{tabular}{|c|c|}
\hline 年 度 & 国際会議/シンポジウム \\
\hline 2010 年 & $\begin{array}{l}\text { 9月 5 9 日 (大阪大学)：国際会議 } \\
\text { IMEKO Symposium ISMQC2010（10th International Symposium on Measurement and Quality Control） } \\
\text { 主 催：知的ナノ計測専門委員会, 大阪大学大学院工学研究科 }\end{array}$ \\
\hline 2011 年 & $\begin{array}{l}\text { 9月 } 20 \text { 日 (金沢大学)：秋季大会学術講演会・シンポジウム } \\
\text { 「光形状計測技術の最新動向」 } \\
\text { 主 催 }: \text { 知的ナノ計測専門委員会, メカノフォトニクス専門委員会 } \\
\end{array}$ \\
\hline 2012 年 & $\begin{array}{l}\text { 3月 } 16 \text { 日 (首都大学東京) : 春季大会学術講演会・シンポジウム } \\
\text { 「高精度の形状・大きさ・寸法を実現するための GPS 規格」 } \\
\text { 主 催 : 知的ナノ計測専門委員会, 日本規格協会 } \\
9 \text { 月 } 16 \text { 日 (九州工業大学) : 秋季大会学術講演会・国際シンポジウム } \\
\text { International Symposium on Technology for Intelligent Measurement with Nanoscale } \\
\text { 主 催 : 知的ナノ計測専門委員会 }\end{array}$ \\
\hline 2013 年 & $\begin{array}{l}3 \text { 月 } 13 \text { 日 (東京工業大学) : 春季大会学術講演会・シンポジウム } \\
\text { 「輪郭曲線・輪郭曲面の測定と定量化法及び三次元の表面性状パラメータ」 } \\
\text { 主 催 : 知的ナノ計測専門委員会, 日本規格協会 }\end{array}$ \\
\hline 2014 年 & 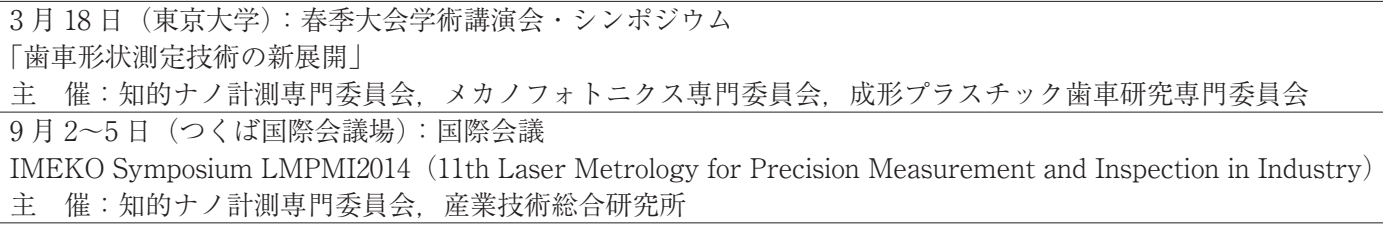 \\
\hline 2015 年 & 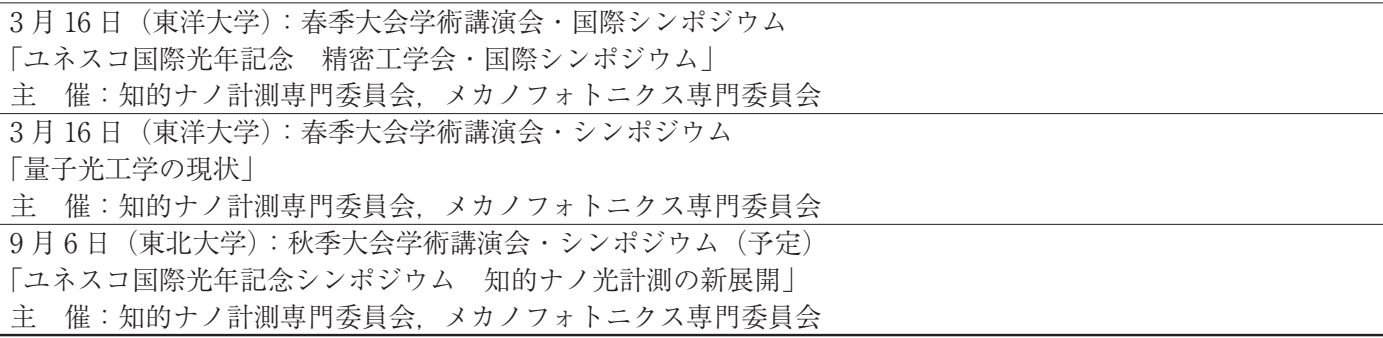 \\
\hline
\end{tabular}

定の基礎についての講義にくわえ，近接場光や X 線を利 用した応用的な精密測定技術の解説および非接触 3D 測定 機を利用した生産性向上・改善の事例について紹介さ れた。

\section{5.お わりに}

知的ナノ計測専門委員会は，設立から 10 年を迎えよう としている，その間，世界のものづくりはめまぐるしく変 化し，計測が担うべき役割も，ますます複雑で高度になっ てきている，精密工学において，計測がものづくりの“横 糸“であることは，これからも変わらないであろう。しか し，設立 10 年という節目を迎えるにあたり，改めて“横 糸“として果たすべき役割を見なおし，さらなる新しい計 測技術の構築と学術としての体系化に務めたい.

\section{参 考 文 献}

1）JIS B 7441 「非接触座標測定機の受入検査及び定期検査」, 2009

2) JIS B 0601-2001, 製品の幾何特性仕様（GPS）表面性状：輪郭 曲線方式, 2001 .

3) ISO 25178-2, Geometrical Product Specifications (GPS) -Surface Texture: Areal一, 2012.
4）尾上太郎, 楊宋珞, 高橋哲, 高増潔, 松本弘一：非接触精密光 コム距離測定技術の開発（第 6 報）一光軸と計測対象面の角度 と計測精度一, 2014 年度精密工学会春季大会学術講演会講演論 文集，（2014）101.

5）石崎祐樹, 林照剛, 道畑正岐, 高谷裕浩: 周波数領域蛍光法を 用いたナノ粒子粒径評価に関する研究（第 3 報）一DNA を用い たナノ粒子計測プローブの開発一, 2014 年度精密工学会春季大 会学術講演会講演論文集, (2014) 93.

6) 丸山泰司, 清水裕樹, 伊藤聡, 高偉 : 光学式 3 軸角度センサの 小型化に関する研究, 2015 年度精密工学会春季大会学術講演会 講演論文集，（2015）151.

7）三隅伊知子, 直井一也, 菅原健太郎, 権太聡 : 測長原子間力顕 微鏡を用いた表面粗さ測定（第 1 報）一JIS R 1683: 2007 に整合 した手法の検討一, 2014 年度精密工学会春季大会学術講演会講 演論文集，（2014） 73 .

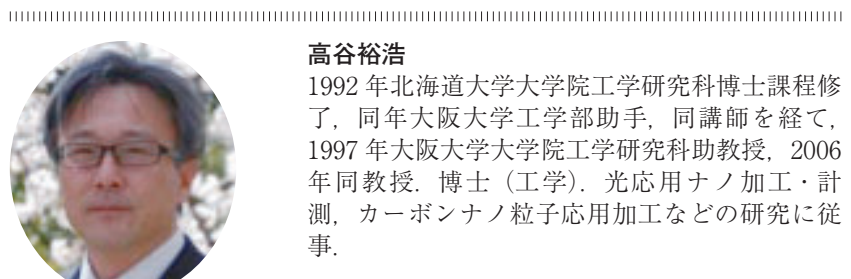

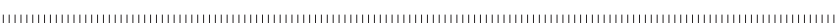

